\title{
HUKUM MENIKAHI WANITA HAMIL SEBAGAI PASSAMPO SIRI DALAM SYARIAT ISLAM
}

\author{
Asnidar Sriyuli, M. H. \\ Universitas Islam Negeri (UIN) Alauddin Makassar \\ Sriyuliasnidar@gmail.com
}

\section{Abstrak}

Pernikahan dalam Islam adalah sesuatu yang sangat ditunggu-tunggu oleh pasangan muda-mudi terutama bagi yang belum pernah mengenal istilah pacaran. Ketika seorang pemuda melamar seorang gadis, antara kedua calon pasangan; hati riang gembira bercampur cemas karena sebentar lagi akan menikah dan mengarungi bahtera rumah tangga. Maka tidak heran pasangan seperti ini, dalam gerak geriknya, tingkah lakunya akan sangat berhati-hati terlebih belum pernah berbicara sebelumnya atau berkomunikasi dan segalanya terasa indah dan mesra. Lain hal ketika sebuah rumah tangga dibangun atau dijalani oleh sepasang suami istri yang sebelumnya sudah pernah berpacaran apalagi sudah sangat jauh dalam hubungannya, semua terasa hambar dan biasa-biasa saja, tidak ada yang spesial, tidak ada yang perlu dibicarakan lagi karena semua telah mengetahui keadaan masing-masing. Terlebih pada pasangan yang menikah dalam keadaan hamil duluan (hamil sebelum menikah).

Keyword: wanita hamil, passampo siri, syariat Islam 


\section{A. Latar Belakang Masalah}

Tuhan menciptakan umat manusia terdiri dari laki-laki dan perempuan, dan menjadikannya berbangsa-bangsa dan bersuku-suku, supaya saling mengenal dan dengan pengenalan itu nantinya lebih jauh akan menghasilkan pertemuanpertemuan dan lebih dalam lagi akan tercapai suatu perjodohan laki-laki dan perempuan di antara umat manusia, karena hidup berjodoh-jodohan adalah naluri segala makhluk Tuhan termasuk manusia.

Menurut ajaran Islam tidak semua wanita boleh dinikahi, ada juga wanita-wanita yang dilarang untuk dinikahi dan hal ini sudah difirmankan oleh Allah dan sudah termaktub dalam Kitab-Nya, juga sudah dijelaskan dalam sabda RasulNya. Namun, kadang hal ini dipahami oleh umatnya dengan tanggapan dan pemahaman yang berbeda-beda, hal ini disebabkan oleh sudut pandang yang berbeda dalam memahami sebuah teks nash karena Tuhan menciptakan kemampuan umatnya tidaklah sama serta dengan keterbatasan-keterbatasannya.

Kemudian ada juga wanita-wanita yang masih diperselisihkan untuk dinikahi, di antaranya ialah wanita pezina. Para ulama ahli fikih berbeda pendapat tentang hal tersebut. ${ }^{1}$ Memang masalah wanita pezina ini sangat kompleks apalagi kalau ditinjau dari keberadaannya, bahwa wanita pezina itu ada sepanjang masa dan zaman, dari sebelum Islam datang sampai Islam datang, wanita pezina ini masih tetap eksis. Kalau di lihat sejarah Nabi, bahwa pada zaman jahiliyah di Madinah terdapat wanita-wanita pezina yang menyewakan diri mereka, yang pada tiap-tiap orang dari mereka terdapat

1 Kamal Mukhtar, Asas-Asas Hukum Islam Tentang Perkawinan (Jakarta: Bulan Bintang, 1993), Hlm. 44.

Sangaji Jurnal Pemikiran Syariah dan Hukum 
tanda di pintunya seperti papan nama dokter hewan (al-baitar), dimaksudkan agar dikenali bahwa ia adalah wanita pezina. ${ }^{2}$

Salah satu akibat dari maraknya pelaku zina adalah kehamilan di luar nikah. Hamil sebelum nikah menjadi problematika yang sangat serius. Problematika ini membutuhkan solusi yang tepat karena hal ini membawa keresahan dalam masyarakat terutama orang tua, guru, tokohtokoh agama dan lainnya. Dari sudut sosiologis, orang tua merasa malu jika mempunyai anak perempuan hamil di luar nikah. Orang tua tentu tidak mau membiarkan anaknya melahirkan tanpa seorang suami, karena hal itu akan menjadi bahan ejekan di kalangan masyarakat. Untuk itu para orang tua berusaha menikahkan putrinya dengan laki-laki yang menghamilinya ataupun bukan, dengan alasan bahwa anak dalam kendungan ketika lahir memiliki ayah. Hal seperti ini dalam masyarakat Bugis-Makassar disebut sebagai perkawinan passampo siri. Maka dari latar belakang di atas, dapat ditarik rumusan masalah sebagai berikut:

1. Apa pengertian perkawinan passampo siri?

2. Bagaimana hukum menikahi wanita hamil sebagai passampo siri dalam syariat Islam?

\section{B. Pengertian Perkawinan Passampo Siri}

Perkawinan berasal dari kata "kawin" yang menurut bahasa berati membentuk keluarga dengan lawan jenis, melakukan hubungan kelamin atau bersetubuh. Berasal dari kata an-nikah yang menurut bahasa berarti mengumpulkan, saling memasukkan, dan wath'i atau bersetubuh. ${ }^{3}$ Berdasarkan Pasal 1 Undang-undang Nomor 1 Tahun 1974 Tentang

${ }^{2}$ Ahmad Rafiq, Hukum Islam di Indonesia (Jakarta: Raja Grafindo Persada, 2000), Hlm. 165.

3 Abdul Rahman Ghozali, Figh Munakahat (Jakarta: Prenada Media Group, 2003), Hlm. 8. 
Perkawinan, Perkawinan adalah ikatan lahir dan batin antara seorang pria dengan seorang wanita sebagai suami istri dengan tujuan membentuk keluarga (rumah tangga) yang bahagia dan kekal berdasarkan Ketuhanan Yang Maha Esa. ${ }^{4}$

Kata siri' dapat juga dapat diartikan sebagai pernyataan sikap yang tidak serakah dan sebuah hidup masyarakat BugisMakassar. Siri' merupakan bangunan moralitas adat, ketika seseorang melakukan perilaku menyimpang, baik dilihat dari perspektif adat yang dilandasi peneguhan harga diri orang Bugis-Makassar. Menurut Shelly Errington, untuk orang BugisMakassar, tidak ada tujuan atau alasan hidup yang lebih tinggi dari pada menjaga siri'nya. ${ }^{5}$ Menurut Prof. Nasir Said berkesimpulan bahwa siri' adalah suatu perasaan malu yang dapat menimbulkan sanksi dari keluarga/family yang dilanggar norma adatnya. ${ }^{6}$

Bagi masyarakat Sulawesi Selatan khususnya BugisMakassar, siri' adalah harga diri atau martabat manusia sebagai manusia yang sebenarnya. Kamus Besar Bahasa Indonesia mengartikan siri' sebagai sistem nilai sosiokultiral kepribadian yang merupakan pranata pertahanan diri dan martabat manusia sebagai individu dan anggota masyarakat dalam masyarakat Bugis.

Sedangkan passampo berarti penutup. Jadi passampo siri' dapat diartikan sebagai penutup malu. Perkawinan passampo siri (Bugis) adalah upaya adat mengawinkan wanita yang sedang hamil dengan laki-laki lain untuk menutup malu. ${ }^{7}$ Satu

4 Undang-Undang Republik Indonesia Nomor 1 Tahun 1974 Tentang Perkawinan dan Kompilasi Hukum Islam ( Bandung: Citra Umbara, 2007), Hlm. 2.

${ }^{5}$ Hamid Abdullah, Siri' dan Pese' (Makassar: Pusat Refleksi, 2007), Hlm. 22.

${ }^{6}$ Mohammad Nasir Said, Siri' Dalam Hubungannya Dengan Perkawinan Adat Masyarakat Mangkasara Sulsel (Makassar: P. Sejahtera, 1962), Hlm. 50.

7 Soerojo Wignjodipoero, Pengantar dan Asas-Asas Hukum Adat, (Cet. VII, Jakarta: PT. Gunung Agung, 1984), h 113.

Sangaji Jurnal Pemikiran Syariah dan Hukum 
hal yang perlu diperhatikan adalah manakala harga diri masyarakat Bugis-Makassar ternodai yang karenanya melahirkan aspek-aspek siri', maka semestinya yang terkena siri' itu melakukan upaya penghapusan siri'.

\section{Hukum Menikahi Wanita Hamil Sebagai Passampo Siri' dalam Syariat Islam}

Terjadi perbedaan pendapat dikalangan para ulama tentang sah tidaknya pernikahan seorang wanita yang sedang hamil dikarenakan zina. Diantara para ulama yang mengatakan bahwa hal itu tidaklah sah baik dengan lelaki yang menzinahinya atau dengan lelaki selainnya adalah para ulama Maliki, Hambali dan Abu Yusuf al Hanafi.

Sedangkan diantara yang membolehkan pernikahan wanita hamil dikarenakan zina adalah para ulama dari Syafi'i, Abu Hanifah dan Muhammad dikarenakan belum tekukuhkannya nasab.

\section{Menurut Imam Abu Hanifah.}

Wanita hamil akibat zina boleh melangsungkan perkawinan dengan laki-laki yang menghamilinya atau dengan laki-laki lain. Wanita hamil karena zina itu tidak ada iddahnya, boleh melangsungkan perkawinan, tetapi tidak boleh melakukan hubungan seks hingga dia melahirkan kandungannya.

Imam Hanafi berpendapat bahwa pernikahan wanita hamil itu tetap boleh dilangsungkan dan sah perkawinannya, hanya saja siapapun suami dari wanita tersebut tidak boleh melakukan hubungan seksual sampai wanita tersebut melahirkan bayi yang dikandungnya dari perbuatan zina tersebut. Ini didasarkan pada hadis Nabi Saw.:

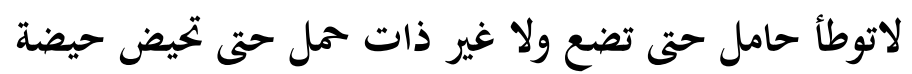


Artinya:

"Jangan kamu melakukan hubungan seks terhadap wanita hamil sampai dia melahirkan dan bagi yang tidak hamil hingga keluar haid satu kali." ${ }^{8}$

\section{Madzhab Syafi'iyah}

Ulama Syafi'iah berpendapat, hukumnya sah menikahi wanita hamil akibat zina, baik yang menikahi itu laki-laki yang menghamilinya maupun bukan yang menghamilinya. Alasannya karena wanita hamil akibat zina tidak termasuk golongan wanita yang diharamkan untuk dinikahi. Mereka juga berpendapat karena akad nikah yang dilakukan itu hukumnya sah, wanita yang dinikahi tersebut halal untuk disetubuhi walaupun ia dalam keadaan hamil. ${ }^{9}$ Imam al-Nawawi menjelaskan bahwa wanita yang hamil karena zina tidak diwajibkan melaksanakan iddah, karena wanita hamil di luar nikah tidak termasuk yang dilarang menikah. Dasar lain yang digunakan mazhab Syafi'i yaitu:

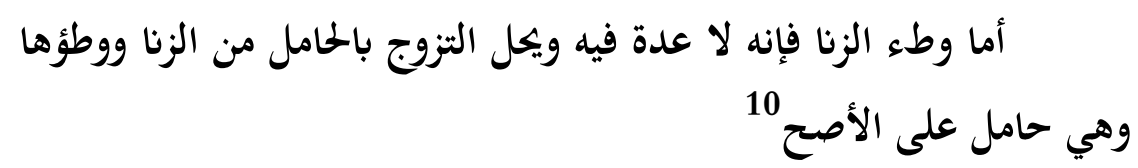

Artinya:

"Hubungan seks karena zina itu tidak ada iddahnya, wanita yang hamil karena zina itu boleh dikawini, dan boleh melakukan hubungan seks sekalipun dalam keadaan hamil."

${ }^{8}$ Abu Daud, SunanAbiDaud, juz. 1(Beirut: Dar al-Fikr, t.tHlm.), Hlm. 654.

${ }_{9}$ Era Muslim Media Islam Rujukan, Menikahi Wanita Yang Dihamili Oleh

Orang Lain, artikel https://www.eramuslim.com/ustadz-menjawab/menikahiwanita-yang-di-hamili-orang-lain.htm, diakses tanggal 30 Mei 2017

10 Wahbah al-Zuhaili, Figh al-Islam wa 'Adillatuh (Bairut: Dar al-Fikr,1985) VII Hlm. 598.

Sangaji Jurnal Pemikiran Syariah dan Hukum 
Menurut mazhab Syafi'i wanita hamil karena zina itu tidak dikenakan ketentuan-ketentuan hukum perkawinan sebagaimana ditetapkan dalam nikah. Karena iddah itu hanya ditentukan untuk menghargai sperma yang ada dalam kandungan istri dalam perkawinan yang sah. ${ }^{11}$ Sperma hasil dari hubungan seks di luar nikah tidak ditetapkan dalam hukum.

\section{Pendapat Imam Malik}

Menurut Imam Malik, kalau laki-laki yang akan menikahi wanita hamil karena zina itu bukan laki-laki yang menghamilinya, Imam Malik berpendapat bahwa pernikahan itu tidak sah. Sebab, wanita yang digauli secara zina status hukumnya persis sama dengan wanita yang digauli secara syubhat. ${ }^{12}$ Wanita tersebut harus mensucikan dirinya dalam waktu yang sama dengan "iddah" wanita yang ditalak suaminya, kecuali bila dikehendaki dilakukan had (hukuman). Kalau dilakukannya had atas wanita yang berbuat zina, pada saat itu dia mensucikan dirinya terhitung sekali haid. ${ }^{13}$

Sedangkan bagi wanita hamil akibat zina, iddahnya sampai ia melahirkan anaknya. Dengan demikian, dalam pandangan Imam Malik iddah wanita hamil karena zina sama dengan iddah wanita hamil dari pernikahan yang sah atau wanita hamil dari persetubuhan yang syubhat. Pandangan Imam Malik tentang kewajiban "iddah" wanita hamil diluar nikah tersebut pada hakikatnya didasarkan

${ }^{11}$ Ibnu Rusyd,Bidayah al-Mujtahid, Juz 2; Beirut : Dar al- Fikr, t.th), Hlm. 21.

12 Persetubuhan syubhat adalah jika seseorang laki-laki dan seorang perempuan melakukan hubungan seksual, karena mereka mengira adalah suami istri, kemudian mereka tahu bahwa mereka bukan suami istri

${ }^{13}$ Mugniyah, Figh Lima Mazhab: ja'fari, Maliki, Hanafi, Syafi'i, Hanbali (Cet. VIII; Jakarta: Lentera, 2002), Hlm. 474. 
pada makna umum dari firman Allah SWT. dalam QS. AtTalaq 65/4:

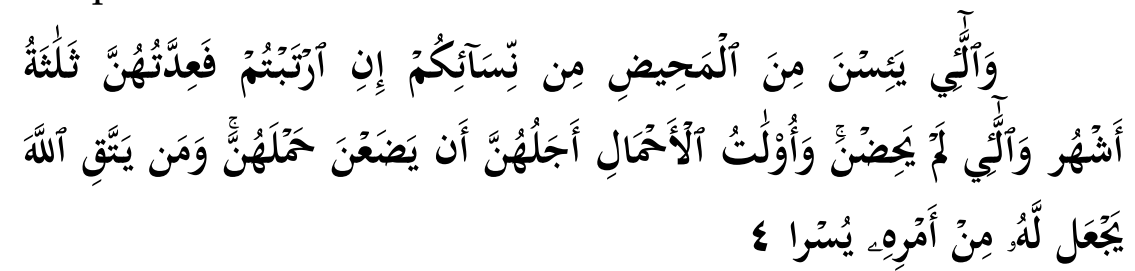

Terjemahnya:

"Dan perempuan-perempuan yang tidak haid lagi (monopause) di antara perempuan-perempuanmu jika kamu raguragu (tentang masa iddahnya), maka masa iddah mereka adalah tiga bulan; dan begitu (pula) perempuan-perempuan yang tidak haid. Dan perempuan-perempuan yang hamil, waktu iddah mereka itu ialah sampai mereka melahirkan kandungannya. Dan barang -siapa yang bertakwa kepada Allah, niscaya Allah menjadikan baginya kemudahan dalam urusannya."14

Oleh karena itu, wanita hamil karena zina mempunyai iddah maka apabila terjadi akad nikah antara wanita hamil karena zina dengan laki-laki selain yang menghamilinya, maka akad nikahnya fasid dan wajib dibatalkan. ${ }^{15}$

\section{Pendapat Abu Yusuf}

Abu Yusuf berpendapat bahwa perkawinan wanita hamil di luar nikah tidak boleh seperti ketidakbolehan perkawinan wanita hamil selain zina. Karena tidak memungkinkan tidur bersama, maka tidak boleh

${ }^{14}$ Departemen Agama RI, al-Qur'an dan Terjemahnya (Bandung: Penerbit J-Art, 2004), Hlm. 558.

${ }^{15}$ Wahbah az-Zuhailii, al-Figh al-Islam wa Adillatuhu. Hlm. 150.

Sangaji Jurnal Pemikiran Syariah dan Hukum 
melaksanakan perkawinan. ${ }^{16}$ Pendapat ini didasarkan pada Q.S. Al Nuur: 3

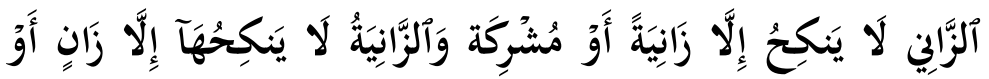

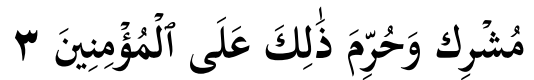

Terjemahnya:

"Laki-laki yang berzina tidak mengawini melainkan perempuan yang berzina, atau perempuan yang musyrik; dan perempuan yang berzina tidak dikawini melainkan oleh laki-laki yang berzina atau laki-laki musyrik, dan yang demikian itu diharamkan atas orang-orang yang mukmin."17

Dari ayat di atas dapat dipahami bahwa wanita hamil di luar nikah lebih pantas kawin dengan laki-laki yang menghamilinya. Selain itu, ayat di atas sekaligus mengisyaratkan bahwa larangan laki-laki yang baik-baik untuk menikahi mereka. ${ }^{18}$ Ibnu Qudamah sependapat dengan Imam Abu Yusuf dan menambahkan bahwa seorang pria tidak boleh menikahi wanita yang diketahuinya telah berbuat zina dengan orang lain, kecuali dengan dua syarat:

a) Wanita tersebut telah melahirkan bila hamil. Jadi jika dalam keadaan hamil tidak boleh menikah.

b) Wanita tersebut telah menjalani hukuman dera. ${ }^{19}$

16 Rahman Ghozali, Fiqh Munakahat (Cet. IV; Jakarta: Kencana, 2010), Hlm. 124.

17 Kementerian Agama RI, al-Qur'an 20 Baris Terjemah (Bandung: CV. Mikraj Khazanah Ilmu, 2013), Hlm. 176.

${ }^{18}$ Ahmad Rafiq, Hukum Islam di Indonesia (Jakarta: Rajagrafindo Persada, 1997), Hlm. 165.

${ }^{19}$ Abdul Rahman Ghozali, Fiqh Munakahat. Hlm. 126-127. 


\section{Madzhab Hambali}

Ulama Hanabilah menentukan dua syarat mengenai kebolehan menikahi wanita yang hamil di luar nikah. Menurut ulama Hanabilah, seseorang laki-laki yang mengetahui seseorang wanita telah berzina, tidak halal menikahi wanita tersebut kecuali dengan dua syarat:

a) Telah habis masa iddahnya, masa iddah wanita hamil sampai anak yang ada di dalam kandungannya lahir. Sebelum anak yang dikandungnya lahir, maka wanita yang hamil di luar nikah tersebut haram menikah. Karena Nabi saw. melarang menyirami hasil tanaman orang lain.

b) Wanita yang hamil di luar nikah telah bertaubat. Sebelum bertaubat, wanita hamil di luar nikah tersebut haram dinikahi oleh seorang yang beriman. ${ }^{20} \mathrm{Hal}$ ini di dasarkan pada Q.S. Al Nuur: 3.

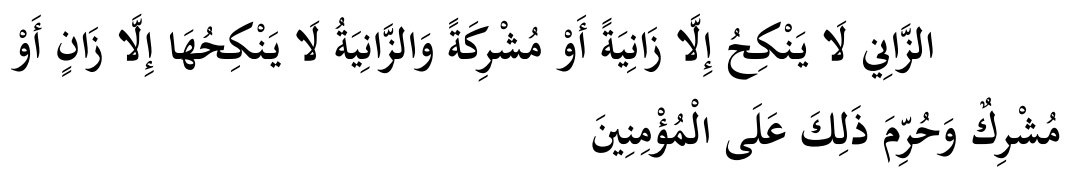

Terjemahnya:

"Laki-laki yang berzina tidak menikahi kecuali dengan perempuan yang berzina atau perempuan yang musyrik dan perempuan yang berzina tidak dikawini melainkan dengan laki-laki yang berzina atau yang musyrik dan itu diharamkan bagi orang-orang yang mukmin." 21

Menikahi wanita hamil korban perbuatan zina dengan lelaki lain, statusnya pernikahan yang batal. Para lelaki dilarang melakukan hubungan dengan wanita yang hamil dengan mani orang lain. Dari Ruwaifi' bin Tsabit Ra., Nabi Saw. bersabda,

${ }^{20}$ Wahbahal-Zuhaili, Figh al-Islam wa 'Adillatuh, Hlm. 598.

${ }^{21}$ Departemen Agama RI, al-Qur'an dan Terjemahnya, Hlm. 350.

Sangaji Jurnal Pemikiran Syariah dan Hukum 


\section{من كان يؤمن بالله واليوم الآخر فلا يسقي ماءه زرع غيره}

Artinya:

"Siapa yang beriman kepada Allah dan hari akhir, janganlah dia menuangkan air maninya pada tanaman orang lain." (HR. Ahmad)

Yang dimaksud tanaman orang lain adalah janin yang disebabkan air mani orang lain. Ancaman dalam hadis ini menunjukkan larangan. Karena itu, tidak ada istilah menolong wanita hamil korban hasil zina dengan bentuk menikahinya. Menikahi wanita hamil, justru menjerumuskannya pada perbuatan zina yang dilegalkan dengan pernikahan yang batal.

Dalam Impres No. 1 Tahun 1991 tentang penyebarluasan Kompilasi Hukum Islam(KHI), Bab VIII Kawin Hamil sama dengan persoalan menikahkan wanita hamil. Pasal 53 dari BAB tersebut berisi tiga (3) ayat, yaitu :

a) Seorang wanita hamil di luar nikah, dapat dinikahkan dengan pria yang menghamilinya.

b) Perkawinan dengan wanita hamil yang disebut pada ayat (1) dapat dilangsungkan tanpa menunggu lebih dulu kelahiran anaknya.

c) Dengan dilangsungkan perkawinan pada saat wanita hamil, tidak diperlukan perkawinan ulang setelah anak yang dikandung lahir.

Persoalan menikahkan wanita hamil apabila dil ihat dari KHI, penyelesaianya jelas dan sederhana cukup dengan satu pasal dan tiga ayat. Yang menikahi wanita hamil adalah pria yang menghamilinya, hal ini termasuk penangkalan terhadap terjadinya pergaulan bebas, juga dalam pertunangan. Asas pembolehan pernikahan wanita hamil ini dimaksudkan untuk memberi perlindungan kepastian hukum kepada anak yang 
ada dalam kandungan, dan logikanya untuk mengakhiri status anak zina.

Fatwa MUI DKI tanggal 26 Dzulqa'dah 1420 tentang perkawinan wanita hamil di luar nikah menyebutkan bahwa wanita yang pernah melakukan zina, baik dalam keadaan hamil dari zina maupun tidak, boleh dan sah dinikah oleh pria yang menzinahinya dan laki-laki lain yang tidak menzinainya. ${ }^{22}$ Adapun fatwa tersebut dapat dijelaskan dengan dalil:

\section{Al Qur'an}

Firman Allah QS Al Nur: 3.

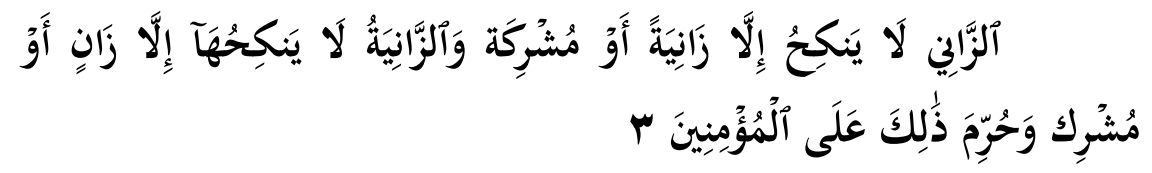

Terjemahnya:

"Laki-laki yang berzina tidak mengawini melainkan perempuan yang berzina, atau perempuan yang musyrik; dan perempuan yang berzina tidak dikawini melainkan oleh laki-laki yang berzina atau laki-laki musyrik, dan yang demikian itu diharamkan atas orang-orang yang mukmin." 23

Ayat diatas menjelaskan, tentang boleh dan sah nya menikahi wanita yang sedang hamil atau tidak karena zina, dengan sesama pria yang menzinainya. Firman Allah dalam Qs. Al Nisa': 24.

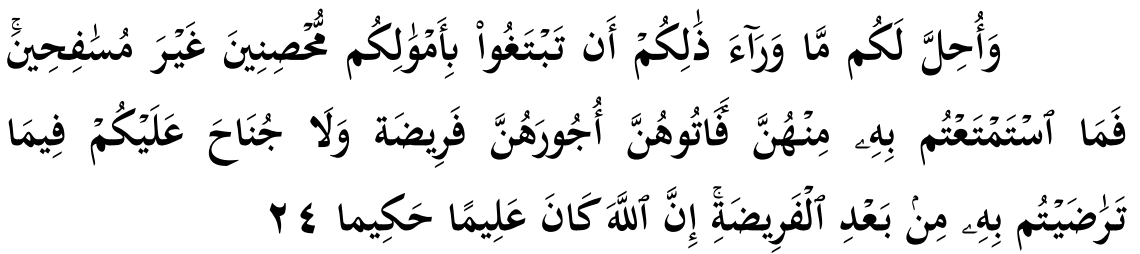

${ }^{22}$ Kumpulan Fatwa MUI Provinsi Daerah Khusus Ibu Kota Jakarta 19752012 (Jakarta: Komisi Fatwa MUI DKI Jakarta, 2012), Hlm. 245

${ }^{23}$ Departemen Agama RI, al-Qur'an dan Terjemahnya, Hlm. 350.

Sangaji Jurnal Pemikiran Syariah dan Hukum 


\section{Terjemahnya:}

"Dan dihalalkan bagi kamu selain yang demikian (yaitu) mencari isteri-isteri dengan hartamu untuk dikawini bukan untuk berzina. Maka isteri-isteri yang telah kamu nikmati (campuri) di antara mereka, berikanlah kepada mereka maharnya (dengan sempurna), sebagai suatu kewajiban; dan tiadalah mengapa bagi kamu terhadap sesuatu yang kamu telah saling merelakannya, sesudah menentukan mahar itu. Sesungguhnya Allah Maha Mengetahui lagi Maha Bijaksana." 24

Dalil diatas menjadi dasar dibolehkannya menikahi wanita yang sedang hamil karena zina dengan orang lain, yang bukan sesama pelaku pezina.

\section{Hadis Nabi}

\section{عن أبي هريرة قال، قال رسول الله صلى الله عليه وسلّم لا ينكح الزّابي الجملود الاّ مثله.(رواه أبو داود)}

Artinya:

"Dari Abi Hurairah ia berkata, Rasulullah Saw telah bersabda: Seorang laki-laki pelaku zina yang dihukum jilid tidak akan menikah kecuali dengan yang serupa (wanita pelaku zina)." (HR. Abu Dawud) $)^{25}$

Hadis diatas menjelaskan bahwa, pelaku pezina hanya akan menikah dengan sesama pezina saja.

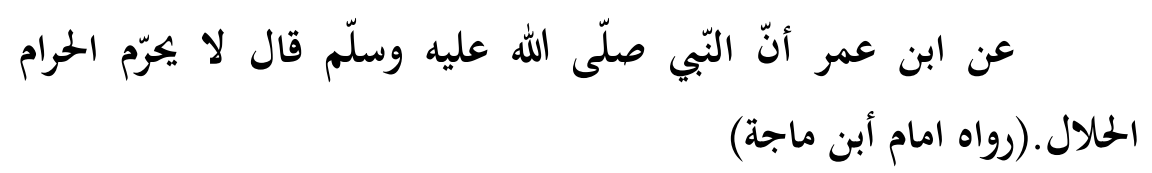

${ }^{24}$ Departemen Agama RI, al-Qur'an dan Terjemahnya, Hlm. 82.

${ }^{25}$ Abi Daud Sulaiman, Sunan Abi Dawud, Hlm. 221. 
Artinya:

"Dari Ibn Umar, Rasulullah Saw telah bersabda: "Perbuatan yang haram (zina) itu tidak menyebabkan haramnya perbuatan yang halal." (HR.Imam Ibn Majah) ${ }^{26}$

Hadis ini menerangkan bahwa, boleh dan sah wanita yang sedang hamil karena zina dinikahi dengan laki-laki lain yang tidak menzinainya, serta sesudah akad mereka boleh melakukan hubungan suami istri, dengan alasan perbuatan yang sudah halal tidak bisa mempengaruhi perbuatan haram yang sebelumnya.

\section{Kaidah Fikih}

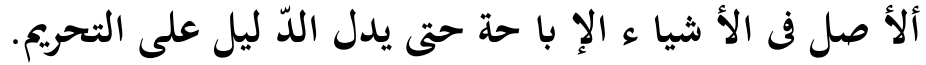

Artinya:

"Asal hukum segala sesuatu adalah boleh, sehingga terdapat dalil yang mengharamkannya."

Maksud dari kaidah ini adalah hukum asal dari menikah adalah boleh tetapi apabila ada dalil yang menunjukkan keharaman tersebut maka hukum nikah berubah menjadi haram. ${ }^{27}$

Lembaga Komisi Fatwa MUI DKI menetapkan pada tanggal 26 Dzulqa'dah 1420 tentang perkawinan wanita hamil di luar nikah menyebutkan, bahwa wanita yang pernah melakukan zina, baik dalam keadaan hamil dari zina maupun tidak, boleh dan sah dinikahi oleh pria yang menzinahinya dan laki-laki lain yang tidak menzinahinya, dengan argumen atau alasan:

${ }^{26}$ Al-Hafiz Abi Abdillah, Sunan Ibn Majah, (Juz 1; Makah: Dar at-Turas al-,,Arabi, ttHlm.),Hlm. 639.

27 Huzaemah T. Yanggo, Figh Perempuan Kontemporer (Jakarta: alMawardi Prima, 2001), Hlm. 45.

Sangaji Jurnal Pemikiran Syariah dan Hukum 
a) Dalam ilmu biologi, sperma yang masuk pada rahim wanita yang sedang hamil tidak akan mempengaruhi janin yang sudah jadi. Dengan demikian, tidak perlu dikhawatirkan akan terjadinya percampuran sperma laki-laki yang menzinai dengan sperma laki-laki yang akan menikahinya secara sah.

b) Jika wanita yang sedang hamil dari zina tidak boleh dinikahi, baik bagi si-pelaku maupun orang lain maka akan menimbulkan rasa malu dan membebani psikologis wanita tersebut, manakala lelaki yang menghamilinya tidak bertanggung jawab.

c) Komisi Fatwa MUI DKI Jakarta lebih cenderung kepada pendapat Imam Syafiei, karena dianggap lebih sesuai dengan kemaslahatan pada masa kini, dilihat dari semakin meningkatnya hubungan pergaulan bebas yang mengakibatkan banyak terjadi kehamilan diluar nikah.

Adapun status nasab anak yang lahir dalam perkawinan wanita hamil dalam KHI dinasabkan kepada suami ibunya hal ini sejalan dengan pendapat Imam Hanafi yang mengaitkan nasabkan kepada pemilik bibit secara umum. Perbedaannya adalah, apabila ternyata pemilik bibit itu bukan orang yang mengawini wanita hamil itu. Imam Hanafi menghubungkannya bukan kepada laki-laki yang mengawininya, tetapi kepada pemilik bibit yang menyebabkan lahirnya anak tersebut. Sedangkan KHI tetap menghubungkan nasab anak kepada laki-laki yang mengawini wanita hamil tersebut.

Bagaimana kalau perkawinannya itu dilangsungkan dalam keadaan hamil tua, maka pendapat Imam Syafi'i lebih menyelamatkan kepada status anak. Karena menurut Imam Syafi'i bahwa pengakuan status anak itu ditentukan dengan masa kehamilan dalam perkawinannya dengan seorang lakilaki, yaitu apabila perkawinannya itu adalah enam bulan, lalu 
anak lahir ,maka anak tersebut memiliki hubungan nasab kepada suaminya. Seandainya kurang dari enam bulan, maka nasab anak tersebut dihubungkan kepada ibunya.

\section{Simpulan}

1. Perkawinan passampo siri (Bugis) adalah upaya adat mengawinkan wanita yang sedang hamil dengan laki-laki lain.

2. Diantara para ulama yang mengatakan bahwa hal itu tidaklah sah baik dengan lelaki yang menzinahinya atau dengan lelaki selainnya adalah para ulama Maliki, Hambali dan Abu Yusuf al Hanafi. Mereka mendasarkan pendapatnya kepada sabda Rasulullah saw., "Seorang wanita yang sedang hamil tidak boleh digauli sehingga dia melahirkan.." (HR. Abu Daud). Sedangkan diantara yang membolehkan pernikahan wanita hamil dikarenakan zina adalah para ulama dari Syafi'i, Abu Hanifah dan Muhammad dikarenakan belum tekukuhkannya nasab, sebagaimana sabda Nabi saw," Anak itu bagi yang memiliki tempat tidur sedang bagi yang berzina tidak memiliki apaapa." (HR. Jama'ah kecuali Abu Daud).

\section{E. Saran}

Dalam pembuatan makalah ini tidak lepas dari beberapa referensi, oleh karenanya penulis mengucapkan banyak terima kasih kepada penulis buku buku yang telah dijadikan referensi dalam pembuatan makalah ini, begitu pun dengan teman teman yag telah memberikan sumbansi dalam penulisan makalah ini. Makalah yang telah penulis susun ini masih jauh dari kesempurnaan, oleh karenanya kritikan dan masukan yang sifatnya membangun sangat penulis harapkan. Terima Kasih

Sangaji Jurnal Pemikiran Syariah dan Hukum 


\section{Daftar Pustaka}

Az-Zuhaili, Wahbah. al-Fikih al-Islam wa Adillatuhu. Bairut: Dar alFikr,1985.

Abdullah, Hamid. Siri' dan Pese'. Makassar: Pusat Refleksi, 2007.

Abdillah, Al-Hafiz Abi. Sunan Ibn Majah. Juz 1; Makah: Dar atTuras al-Arabi, tth.

Departemen Agama RI, al-Qur'an dan Terjemahnya . Bandung: J-Art, 2004.

Ghozali, Abdul Rahman. Fikih Munakahat. Jakarta: Prenada Media Group, 2003.

, Abdul Rahman. Fikih Munakahat. Cet. IV; Jakarta: Kencana, 2010.

Kementerian Agama RI. al-Qur'an 20 Baris Terjemah. Bandung: CV.

Mikraj Khazanah Ilmu, 2013.

Kementerian Agama RI, al-Qur'an 20 Baris Terjemah. Bandung: CV. Mikraj Khazanah Ilmu, 2013.

Kumpulan Fatwa MUI Provinsi Daerah Khusus Ibu Kota Jakarta 1975-2012. Jakarta: Komisi Fatwa MUI DKI Jakarta, 2012.

Mugniyah. Fikih Lima Mazhab: ja'fari, Maliki, Hanafi, Syafi'i, Hanbali.

Cet. VIII; Jakarta: Lentera, 2002.

Rafiq, Ahmad. Hukum Islam di Indonesia. Jakarta: Rajagrafindo Persada, 1997.

Rusyd, Ibnu. Bidayah al-Mujtahid, Juz 2; Beirut : Da>r al- Fikr, t.th.

Said, Mohammad Nasir. Siri' Dalam Hubungannya Dengan Perkawinan Adat Masyarakat Mangkasara Sulsel. Makassar: P. Sejahtera, 1962.

Sulaiman, Abu Daud. SunanAbi Daud. (Beirut: Dar al-Fikr, t.th.), juz. 1

Undang-Undang Republik Indonesia Nomor 1 Tahun 1974 Tentang

Perkawinan dan Kompilasi Hukum Islam. Bandung: Citra

Umbara, 2007.

Wignjodipoero, Soerojo. Pengantar dan Asas-Asas Hukum Adat. Cet. VII, Jakarta: PT. Gunung Agung, 1984. 
358 | Asnidar Sriyuli

Yanggo, Huzaemah T. Fikih Perempuan Kontemporer. Jakarta: alMawardi Prima, 2001

Sangaji Jurnal Pemikiran Syariah dan Hukum 